OPEN ACCESS

Al Aijaz Research Journal of

Islamic Studies \& Humanities

ISSN (ONLINE): 2707-1219

ISSN (PRINT): 2707-1200
ARJISH, Vol: 5, Issue: 3 ,

July to September 2021

DOI: 10.53575/arjish.v5.3(21)E2.12-25

http://www.arjish.com

\title{
A Synchronic Study on Learners' Perceptions about Online English Language Teaching during the COVID-19 in Pakistan
}

Muhammad Amjad*

Dr. Riaz Hussain**

Dr. Muhammad Asif ${ }^{* * *}$

\begin{abstract}
This is a synchronic study in which the researchers have tried to explore Pakistani ESL learners' perceptions about the effectiveness of online English language teaching during the COVID-19 pandemic. The researchers used descriptive survey research design, and a structured questionnaire was used for data collection. Population of the study was the BS level students who had studied English through online mode of education during the COVID-19 pandemic. 100 respondents were selected from the population through simple random sampling technique. Cronbach's alpha test was used to check the reliability of the questionnaire, whereas validity was maintained by asking different research experts to review the questionnaire keeping in mind the research questions. Data analysis through SPSS revealed that online English language teaching during the COVID-19 pandemic proved useful for the listening skills ( $42 \%$ very useful, $30 \%$ useful), reading skills ( $30 \%$ very useful, $26 \%$ useful) and vocabulary (14\% very useful, $45 \%$ useful) of the Pakistani ESL learners. Moreover, $64 \%$ agreed (10 $\%$ strongly agree, $54 \%$ agree) with the view that online English language teaching during the pandemic remained student centered. The Pakistani ESL learners were also satisfied with lectures' time duration, teachers' feedback and online examinations of English subject during the COVID-19 pandemic. On the whole, $72 \%$ (44\% to a great extent and $28 \%$ to a very great extent) of the respondents indicated that online English language teaching during the pandemic yielded positive results to a great extent.
\end{abstract}

Keywords: Online English Language Teaching, COVID-19, Pakistani ESL Learners

\section{Introduction}

COVID-19 has become a word that echoes many times in our minds every day. Its first case seems to have been discovered in China (Huang et al. 2020) ${ }^{1}$ and the World Health Organization (WHO) declared it a pandemic in March, 2020 with an additional precautionary measure of social distancing as a means to stop the spread of coronavirus (World Health Organization 2020)..$^{2}$ Since then the world came to a halt. There were lockdowns. Industries were closed; unemployment reached to its new heights. Even the religious places belonging to different religions were also closed. In this way, COVID-19 being primarily a global health issue caused many other multifaceted problems. Closure of educational institutions because of COVID-19 is one of the problems whose impact will definitely be felt in future. According to Li and Lalani (2020), over 1.2 billion children in 186 countries were out of classroom because of COVID-19 lockdowns and this resultantly marked a sudden shift from classroom

\footnotetext{
* PhD Scholar, Department of English Linguistics, Islamia University Bahawalpur, Punjab, Pakistan.

Email:amjad41008@gmail.com

${ }^{* *}$ Department of English Linguistics, The Islamia University Bahawalpur, Punjab, Pakistan.

Email: dr.riazhussain@iub.edu.pk

${ }^{* * *}$ Department of English, Ghazi University Dera Ghazi Khan, Punjab, Pakistan.

Email: uasif@gudgk.edu.pk
} 
education to online education across the globe in order to continue education even in emergency circumstances. ${ }^{3}$ According to Yu (2020), 260 million children started taking online classes in China because of COVID-19.4 Even UNESCO put forward recommendations of online learning for uninterrupted education during the lockdown period (The United Nations Educational, Scientific and Cultural Organization 2020). ${ }^{5}$ Keeping in mind the recommendations of UNESCO and the prescribed precautionary measures of WHO, many countries observed a paradigm shift from classroom learning to online learning. Educational services through online mode of learning remained available in a large number of countries including Indonesia (Thaheem et al. 2021) ${ }^{6}$, India (Mathivanan et al. 2021) ${ }^{7}$, Iran (Ahmady, Shahbazi and Heidari $2020^{8}$; Younesi 20219), Saudi Arabia (Oraif and Elyas 2021) ${ }^{10}$, the USA (Asgari et al. 2021) ${ }^{11}$, and Germany (König, Jäger-Biela and Glutsch 2020) ${ }^{12}$. Pakistan is no exception in this regard. Pakistan also managed to continue educational services through online mode of learning and it also faced challenges and obstacles like that of other developing countries. There were many challenges and studies ( See, for example, Farooq, Rathore and Mansoor 2020 ; 13, Khan and Jawaid $2020^{14}$ and Mumtaz, Saqulain and Mumtaz 202115) have already pointed out the challenges that online learning posed during the pandemic in Pakistan; yet no or few studies have been conducted in Pakistan to explore the effectiveness of online English teaching process in Pakistan. Thus the current research work investigates the Pakistani ESL learners' perceptions about online English language teaching process and its effectiveness despite the presence of many challenges.

\section{Significance of the Study}

The study and its findings can be significant for the teachers, educationists, researchers and policy makers. The findings of the current research should of interest to the educationists and policy makers who are constantly deliberating on possible solutions to the educational crisis as a result of COVID-19 in Pakistan. The measures taken by the teachers and the educationists, keeping in mind the findings of this study, can prove to be beneficial for the English language learners in future. The current research also adds some new findings in the existing researches on online English language teaching-learning practices during the pandemic COVID-19.

\section{Research Questions}

1. What do the Pakistani ESL learners think about the usefulness of online English language teaching during the COVID-19 pandemic?

2. What perceptions do the Pakistani ESL learners have specifically regarding the methodology of online English language teaching during the COVID-19 pandemic?

3. What do the Pakistani ESL learners think about the overall effectiveness of online English language teaching during the COVID-19 pandemic?

\section{Literature Review}

The rise of COVID-19 and imminent lockdowns made online teaching and learning inevitable. The selection of online teaching and learning during the COVID-19 was not without due deliberations because many theorists and researchers have authenticated the benefits of online education in the past. Online mode of learning yields positive results because it uses 
multiple verbal and visual resources in order to make the learners grasp the key concepts. The Dual Coding Theory and Cognitive Theory of Multimedia Learning support this view that learning becomes easy when educators integrate verbal and visual tools in their lectures. The Dual Coding Theory and Cognitive Theory of Multimedia Learning have been discussed below.

\section{Dual Coding Theory (DCT)}

Dual Coding Theory was presented by Allan Paivio in 1971. According to this theory human cognition is divided into two processing systems: verbal and visual. Verbal system deals with linguistic processing while visual system aids the processing of graphical information (Paivio and Clark 2006). ${ }^{16}$ Moreover, the chances of acquisition for learners would be doubled, if the information is to be presented and coded both visually and verbally (Paivio and Clark 2006).17 The schematic representation of DCT is given below.

Figure 1: Dual Coding Theory (DCT)

\section{Allan Paivio's Dual-Coding Theory}

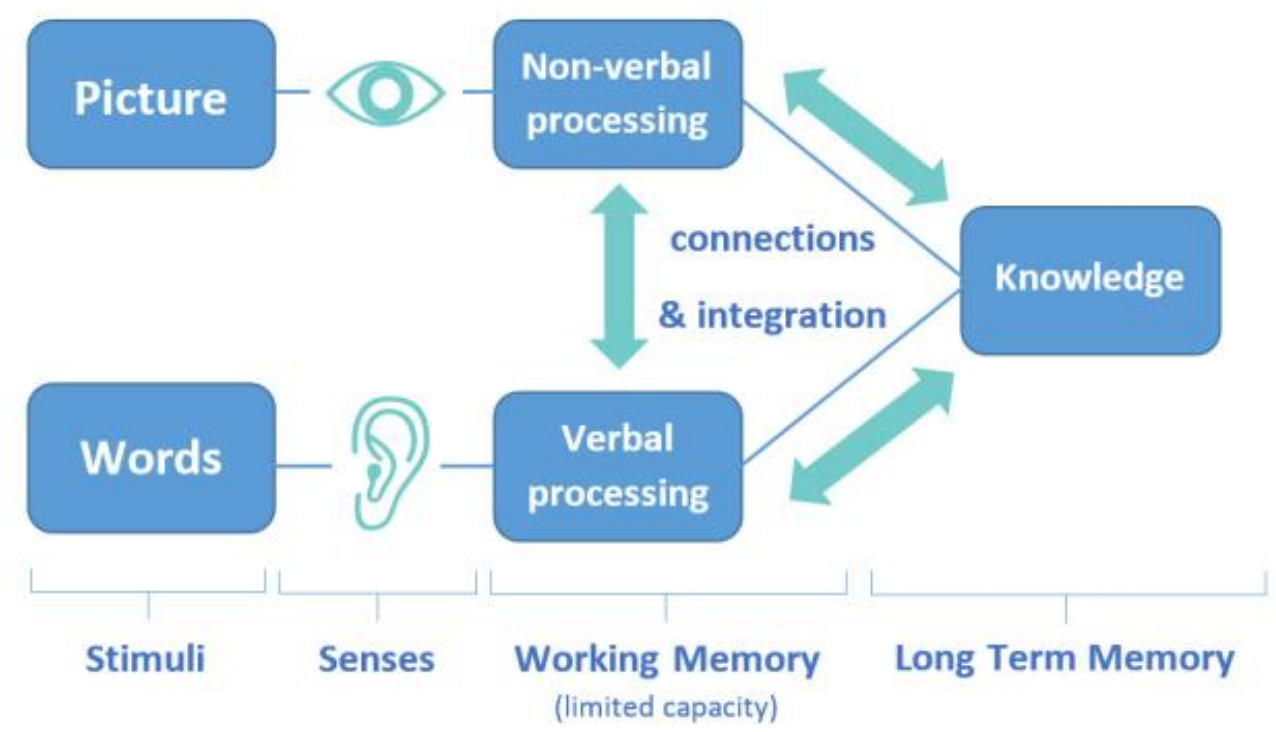

Keeping in mind the current scenario of online education because of the COVID-19 pandemic, it can be fairly argued that the educators can make use of DCT by adding both visual and verbal sources of information in their online teaching lessons in order to achieve better results. Apart from Dual Coding Theory, Cognitive Theory of Multimedia Learning (CTML) can also provide help to the educators on how to use multimedia effectively in the current scenario of online education because of the COVID-19 pandemic. Cognitive Theory of Multimedia Learning (CTML) is discussed below.

\section{Cognitive Theory of Multimedia Learning (CTML)}


This theory was popularized by Richard E. Mayer who gave the idea that learning can be made more comprehensible by presenting verbal and visual resources simultaneously. The schematic representation of CTML is given below.

Figure 2: Cognitive Theory of Multimedia Learning (CTML)

\section{Cognitive theory of multimedia learning}

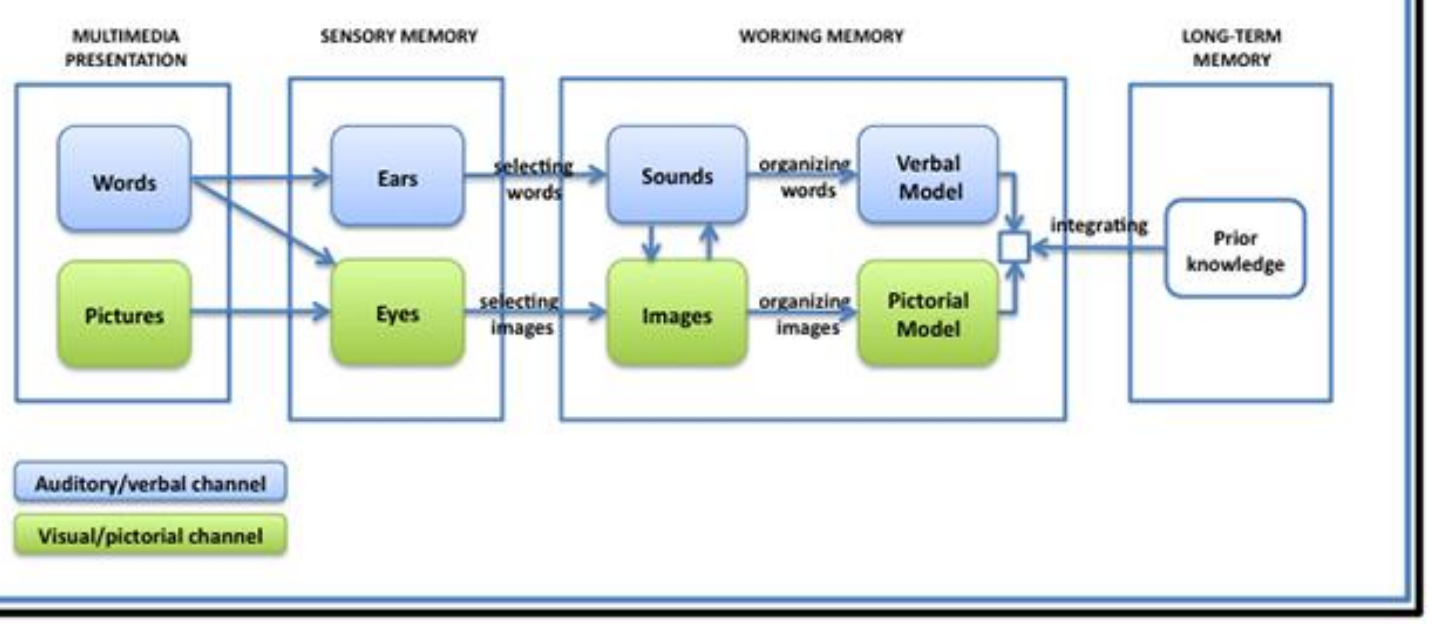

According to Mayer (2005), the learners build meaningful connections between the words and pictures in their working memory, as a result they learn more deeply than they could have with words or pictures alone.18 Dual Coding Theory (DCT) and Cognitive Theory of Multimedia Learning (CTML) remain same up to this point. The difference lies in the next point that DCT does not specify how to use verbal and visual resources while CTML theory outlines some guiding principles for the educators how to integrate both verbal and visual resources in order to make their teaching process better and comprehensible. According to CTML, simply adding words to pictures is not an effective way to achieve comprehensible learning. The need is to present both verbal and visual resources in such a way that human cognition may grasp both the resources easily. This can be achieved by following certain guiding principles given by Johnson and Mayer. Some of the key principles are discussed in the following lines. The instructors should not include such extraneous information in their multimedia learning that will not be assessed in future. Such extraneous information either verbal or visual will overload the memory and important information will be overlooked by the learners. Moreover, the instructors should use cues like arrows and highlighting in order to make organization of whole material understandable. Furthermore, he warns that instructors should not add on-screen text with verbal resources as he argues that "People learn more deeply from pictures and spoken words than from pictures and printed words" (p. 200). He further argues that both verbal and visual resources should be presented simultaneously rather than successively (Mayer 2009). ${ }^{19}$ 
The above mentioned Dual Coding Theory (DCT) and Cognitive Theory of Multimedia Learning (CTML) provide the rationale to use online mode of education during the COVID-19 pandemic. The outbreak of the coronavirus forced many countries, as mentioned in Introduction section, to make a sudden shift from physical face to face education to online mode of education. As a result, many researches have been conducted on online education during the COVID-19 pandemic but still there remains a research gap. Therefore in the next section, the researchers will identify the research gap by discussing some key researches related to the current research work.

\section{Previous Researches and the Research Gap}

Several aspects related to online teaching and learning during the COVID-19 have been discussed by different researchers and educationists. Shahzad et al. (2020) discussed the effect of online teaching on ESL learners' attitudes under COVID-19 circumstances in Pakistan. According to them, the learners showed positive attitude towards online teaching during the COVID-19 circumstances. Learners showed positive attitude because they found online teaching during COVID-19 a happy experience which motivated them and the teachers were also easily accessible. ${ }^{20}$ Thus online teaching-learning remained a positive factor for the learners. Some other studies also support the above mentioned study and consider online teaching-learning process during COVID-19 an advantageous factor for the learners. As cited in Yu (2020), Francis Miller, the Director of College Counseling at Xi'an Tieyi High School International Curriculum Center, considers that online teaching-learning process provides equal opportunity for all poor and the rich. The worthy director avers, "For perhaps the first time, all students in China - rich and poor, urban and rural - have equal access to classes with the most experienced and best-trained teachers. All it took to make it happen was an epidemic." 21

$\mathrm{Li}$ and Lalani (2020) argue that though there are certain speculations that sudden shift to online mode of learning with no training and little preparation will result in a poor user experience while others consider that a new hybrid model of education will emerge, with significant benefits. ${ }^{22}$ It means that pandemic led changes in mode of education will prove beneficial and might be here to stay in future. Same view is supported by Wang Tao who is the vice president of a Chinese multinational technology company named Tencent Cloud and Education. According to him, "I believe that the integration of information technology in education will be further accelerated and that online education will eventually become an integral component of school education" (as cited in Singh and Tiwari 2021).23

Moreover, online education during the pandemic circumstances has led to introduce a unique platform named VIPKid (https://www.vipkid.com/). ${ }^{24}$ VIPKid is a sort of online global classroom where students from across different countries get connected and get real-time online education. This online platform provides Mathematics and English courses for the learners. It connects more than 700,000 students with 100,000 teachers in Canada and the United States for online teaching-learning process. VIPKid founder and CEO, Cindy Mi, a high school dropout herself, once dreamt of building a global classroom with global teachers. Those dreams have been realized through VIPKid, which facilitates learning and cultural connections at a historically unprecedented scale (as cited in Yu 2020). ${ }^{25}$ 
Furthermore, Harrison (2020) argues that online education because of COVID-19 became the cause of professional development for the teachers. He further says that sudden move towards online education because of COVID-19 lockdowns motivated Cambridge English Organization (https://www.cambridgeenglish.org/) to take a historical step to initiate free teachers' training course on how to teach online English classes so they may well equipped to teach online English classes during the pandemic-19. The first iteration of this course attracted over 50,000 participants. ${ }^{26}$

Though the major focus of studies on online education during the pandemic remained on exploring its benefits, several researches also explored the challenges that online education faced during the COVID-19. Mumtaz, Saqulain and Mumtaz (2021) described several challenges that the Pakistani online education system faced during the COVID-19 pandemic. Accessibility to technology, teachers' training and assessment problems were the main challenges explored by the aforementioned study. ${ }^{27}$ Rehman (2020) points out the challenge of online content production for the Pakistani educators during the COVID-19. According to him, in the digital world, a two-hour lesson takes up to six hours of documenting and preparation. He also points out that the institutions were unable to bear expenditures and pay their employees. Moreover, technological problems were also common such as learning management systems (LMS), the backbone of online education of many institutions, were vulnerable to crash. ${ }^{28}$

From the above discussion, it can be argued that the primary concern of majority of researches on online teaching and learning during the pandemic-19 remained on the following aspects. 1) Learners' attitude towards online learning. 2) Advantages of online paradigm of learning during the COVID-19 pandemic. 3) Multifaceted challenges faced by the learners and educators because of sudden move from classroom learning to online mode of learning. However, research on online teaching-learning during the pandemic in relation to a specific field/subject of study has been a research gap. The current research work fills this research gap and explores effectiveness of online mode in relation to a specific field or subject i.e. English language teaching. In this way the researchers have tried to explore learners' perceptions about i) the usefulness of online teaching in relation to specific English language skills during the COVID-19 pandemic ii) online English teaching methodology during the COVID-19 pandemic, and iii) the overall effectiveness and likeability of online English teaching during the COVID-19 pandemic. Thus, the current research fills the research gap by exploring different aspects of online mode of education in relation to English language teaching during the COVID-19 pandemic.

\section{Research Methodology}

This is a synchronic study which takes into account the Pakistani ESL learners' perceptions about online English language teaching during the COVID-19 pandemic from March 2020 to February 2021 (12 months). The researchers used descriptive survey research design, and a structured questionnaire was used for the collection of data. All the items in the questionnaire were closed ended. Moreover, it consisted of three sections and these sections dealt with the following aspects of online English language teaching. 1) The Pakistani ESL learners' perceptions about the usefulness of online teaching in relation to specific English language skills during the COVID-19 pandemic.2) The Pakistani ESL learners' perceptions about online 
English language teaching methodology during the COVID-19 pandemic. 3) The Pakistani ESL learners' perceptions about the overall effectiveness of online English language teaching during the COVID-19 pandemic. Population of the study was the BS level students who had studied English through online mode of education during the COVID-19 pandemic. 100 respondents were selected from the population through simple random sampling technique. The participants were already informed about the research objectives and they were free to choose whether to become the part of research or not. Cronbach's alpha test was used to check the reliability of the questionnaire, whereas validity was maintained by asking different research experts to review the questionnaire keeping in mind the research questions. Research setting was district Layyah. Data collected from the questionnaire was coded and entered into SPSS for analysis.

\section{Data Analysis}

\section{Reliability and Validity of the Questionnaire}

Reliability or internal consistency of the grouped items was checked by using Cronbach's alpha test. Trizano-Hermosilla and Alvarado (2016) also recommend Cronbach's alpha for estimating reliability of an instrument. ${ }^{29}$ George and Mallery (2003) put forward the following criteria of Cronbach's alpha test while estimating the reliability of an instrument. ${ }^{30}$

\section{Figure 3: Reliability Criteria}

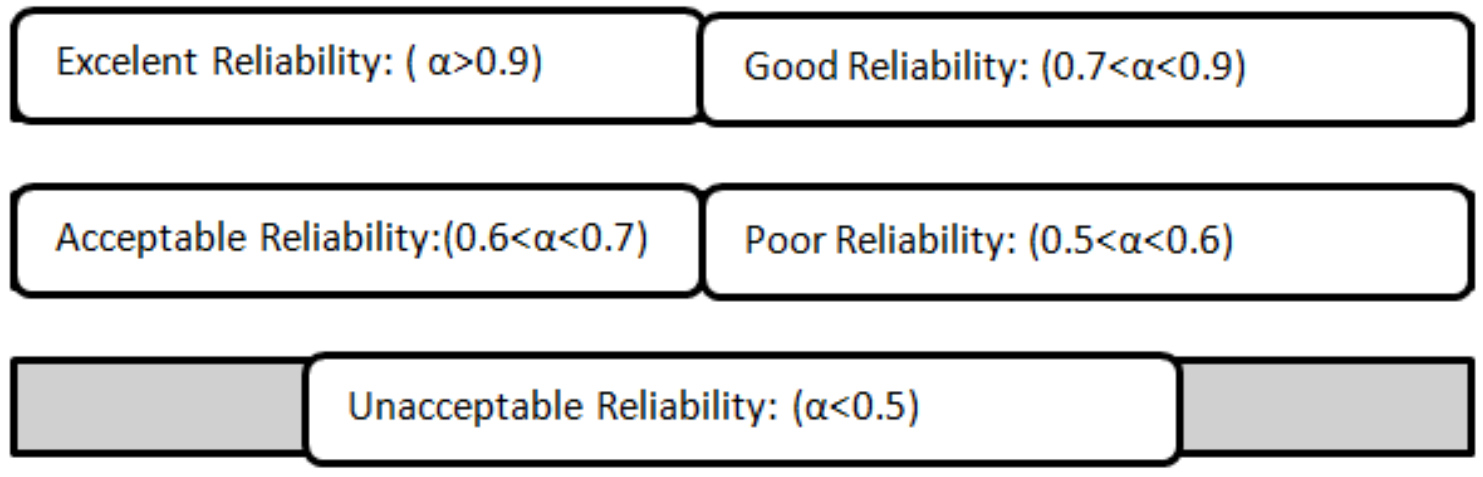

SPSS was used to check the reliability of the questionnaire. The following table shows the reliability results of the current study.

Table 1: Summary of the reliability statistics

$\begin{array}{lccc}\text { Sections } & \begin{array}{c}\text { No. } \\ \text { of } \\ \text { Items }\end{array} & \begin{array}{c}\text { Cronbach's } \\ \text { Alpha }\end{array} & \text { Reliability } \\ \begin{array}{l}\text { Section A: The Pakistani ESL Learners' Perceptions } \\ \text { about the Usefulness of Online Teaching in Relation } \\ \text { to Specific English Language Skills during the COVID- }\end{array} & 6 & 0.848 & \text { Good } \\ \begin{array}{l}19 \text { Pandemic } \\ \text { and }\end{array} & & & \end{array}$


Section B: The Pakistani ESL Learners' Perceptions about Online English Language Teaching Methodology during the COVID-19 Pandemic

Section C: The Pakistani ESL Learners' Perceptions about the Overall Effectiveness and Likeability of

Online English Teaching during the COVID-19

Pandemic

The abovementioned Cronbach's alpha values in Table 1 show that questionnaire's reliability was Good, Acceptable and Good in Sections A, B and C respectively. Acceptable coefficient alpha values allowed the researchers to go for further analysis. On the other hand, content validity was maintained by asking different research experts to review the questionnaire keeping in mind the research objectives and questions.

\section{Analysis of Section A}

Section A consisted of different questions that helped the researchers to explore the Pakistani ESL learners' perceptions about the usefulness of online teaching in relation to specific English language skills during the COVID-19 pandemic. Results of Section A are shown in terms of percentage in Table 2.

Table 2: The Pakistani ESL Learners' Perceptions about the Usefulness of Online Teaching in Relation to Specific English Language Skills during the COVID-19 Pandemic

\begin{tabular}{|c|c|c|c|c|}
\hline Question No. \& Statement & $\begin{array}{l}\text { Very } \\
\text { Useful }\end{array}$ & Useful & $\begin{array}{c}\text { Somewhat } \\
\text { Useful }\end{array}$ & $\begin{array}{c}\text { Not } \\
\text { Useful }\end{array}$ \\
\hline $\begin{array}{l}\text { A.1. To what extent, you perceive, online } \\
\text { teaching proved to be useful in improving your } \\
\text { writing skills of English language during the } \\
\text { COVID-19 pandemic. }\end{array}$ & $14 \%$ & $32 \%$ & $29 \%$ & $25 \%$ \\
\hline $\begin{array}{l}\text { A.2. To what extent, you perceive, online } \\
\text { teaching proved to be useful in improving your } \\
\text { reading skills of English language during the } \\
\text { COVID-19 pandemic. }\end{array}$ & $30 \%$ & $26 \%$ & $29 \%$ & $15 \%$ \\
\hline $\begin{array}{l}\text { A.3. To what extent, you perceive, online } \\
\text { teaching proved to be useful in improving your } \\
\text { listening skills of English language during the } \\
\text { COVID-19 pandemic. }\end{array}$ & $42 \%$ & $30 \%$ & $15 \%$ & $13 \%$ \\
\hline $\begin{array}{l}\text { A.4. To what extent, you perceive, online } \\
\text { teaching proved to be useful in improving your } \\
\text { speaking skills of English language during the } \\
\text { COVID-19 pandemic. }\end{array}$ & $17 \%$ & $27 \%$ & $30 \%$ & $26 \%$ \\
\hline $\begin{array}{l}\text { A.5. To what extent, you perceive, online } \\
\text { teaching proved to be useful in improving your } \\
\text { grammar of English language during the } \\
\text { COVID-19 pandemic. }\end{array}$ & $15 \%$ & $30 \%$ & $41 \%$ & $14 \%$ \\
\hline
\end{tabular}




$\begin{aligned} & \text { A.6. To what extent, you perceive, online } 14 \% \\ & \text { teaching proved to be useful in improving your }\end{aligned}$
vocabulary of English language during the
CoviD-19 pandemic.

The above mentioned table shows that $46 \%$ of the respondents(14 \% very useful and $32 \%$ useful) opine that online English language teaching during the COVID-19 pandemic proved useful for their writing skills, whereas56\% (30\% very useful and $26 \%$ useful ) opine that the online English language teaching during the pandemic proved useful for their reading skills. Moreover, $72 \%$ (42\% very useful and $30 \%$ useful) think that the online English language teaching during the COVID-19 pandemic proved useful for their listening skills. Less than half $44 \%$ of the respondents (17\% very useful and $27 \%$ useful) perceive that online English language teaching during the COVID-19 pandemic improved their speaking skills. 45 $\%$ of the respondents think that the online English language teaching during the COVID-19 pandemic proved to be useful (15\% very useful and $30 \%$ useful) for grammar while $59 \%$ of the respondents ( $42 \%$ very useful and $30 \%$ useful) think that the online English language teaching during the COVID-19 pandemic improved their vocabulary.

\section{Analysis of Section B:}

Section B consisted of different questions that helped the researchers to explore the Pakistani ESL learners' perceptions about online English language teaching methodology used by the teachers during the COVID-19 pandemic. Analysis results of Section B are shown in Table 3.

Table 3: The Pakistani ESL Learners' Perceptions about Online English Language Teaching Methodology during the COVID-19 Pandemic

\begin{tabular}{|lccccc|}
\hline Question No. \& Statement & $\begin{array}{l}\text { Strongly } \\
\text { Disagree }\end{array}$ & Disagree & Uncertain & Agree & $\begin{array}{c}\text { Strongly } \\
\text { Agree }\end{array}$ \\
\hline $\begin{array}{l}\text { B.1.My English language teacher used } \\
\text { to deliver lectures in English regularly } \\
\text { during the COVID-19 pandemic. }\end{array}$ & $3 \%$ & $11 \%$ & $16 \%$ & $60 \%$ & $10 \%$ \\
\hline $\begin{array}{l}\text { B.2. My English language teacher used } \\
\text { to deliver lectures with the help of AV } \\
\text { aids while teaching online during the } \\
\text { COVID-19 pandemic. }\end{array}$ & $3 \%$ & $10 \%$ & $11 \%$ & $53 \%$ & $23 \%$ \\
\hline $\begin{array}{l}\text { B.3. Online English language teaching } \\
\text { during CovID-19 pandemic period was } \\
\text { student-centered. }\end{array}$ & $6 \%$ & $19 \%$ & $11 \%$ & $54 \%$ & $10 \%$ \\
\hline $\begin{array}{l}\text { B.4. My English language teacher } \\
\text { regularly used to allot time for } \\
\text { questions at the end of online lecture } \\
\text { during the COVID-19 pandemic. }\end{array}$ & & & & & \\
\hline $\begin{array}{l}\text { B.5. My English language teacher used } \\
\text { to employ such type of online activities } \\
\text { that encouraged us to interact with } \\
\text { each other in English during the } \\
\text { CoviD-19 pandemic. }\end{array}$ & & $23 \%$ & $24 \%$ & $24 \%$ & $18 \%$ \\
\hline
\end{tabular}




\begin{tabular}{|c|c|c|c|c|c|}
\hline $\begin{array}{l}\text { B.6. My English language teacher used } \\
\text { to provide feedback whenever I asked } \\
\text { questions in online classes during the } \\
\text { COVID-19 pandemic. }\end{array}$ & $2 \%$ & $17 \%$ & $27 \%$ & $50 \%$ & $4 \%$ \\
\hline $\begin{array}{l}\text { B.7. My final online examinations of } \\
\text { English subject were conducted } \\
\text { smoothly during the CoVID-19 } \\
\text { pandemic. }\end{array}$ & $2 \%$ & $7 \%$ & $31 \%$ & $47 \%$ & $13 \%$ \\
\hline $\begin{array}{l}\text { B.8. My English language teacher used } \\
\text { to assess our progress during online } \\
\text { lectures on regular basis during the } \\
\text { COVID-19 pandemic. }\end{array}$ & $4 \%$ & $26 \%$ & $38 \%$ & $31 \%$ & $1 \%$ \\
\hline $\begin{array}{l}\text { B.9. Time duration of online English } \\
\text { language classes/lectures during the } \\
\text { COVID-19 pandemic was adequate. }\end{array}$ & $1 \%$ & $6 \%$ & $18 \%$ & $51 \%$ & $24 \%$ \\
\hline $\begin{array}{l}\text { B.10. During the COVID-19 pandemic, } \\
\text { overall screen layout and window } \\
\text { design of the system for online English } \\
\text { language classes was appropriate. }\end{array}$ & $3 \%$ & $11 \%$ & $22 \%$ & $56 \%$ & $8 \%$ \\
\hline
\end{tabular}

Table 3 shows that $70 \%$ of the respondents agree (60 \% agree and $10 \%$ strongly agree) that their English language teachers used English as a medium of instruction for online English language teaching during the COVID-19 pandemic. $76 \%$ agree $(53 \%$ agree and $23 \%$ strongly agree)with the statement that their English language teachers used to deliver lectures with the help of AV aids while teaching online during the COVID-19 pandemic, whereas $64 \%$ (54 $\%$ agree and $10 \%$ strongly agree) consider online English language teaching during pandemic period was student centred. Moreover, $62 \%$ agree (57 \% agree and $5 \%$ strongly agree) with the statement that their English language teachers regularly used to allot time for questions at the end of online lectures during the pandemic. Less than half $42 \%$ agree $(24 \%$ agree and $18 \%$ strongly agree) that their English language teachers used to employ interactive activities. Altogether $54 \%$ agree (50\% agree and $4 \%$ strongly agree) that their English language teachers used to provide feedback whenever they asked questions during the pandemic. $60 \%$ (47 \% agree and $13 \%$ strongly agree) think that their online examination of English subject was smoothly conducted during the pandemic. Only $32 \%$ agree (31\% agree and $1 \%$ strongly agree) that their English language teachers used to assess their progress during online lectures on regular basis during the pandemic while $75 \%$ (51\% agree and $24 \%$ strongly agree) were satisfied with the time duration of online English language lectures during the pandemic.64\% of the respondents (56\% agree and $8 \%$ strongly agree) consider overall screen layout and window design of the system for online English language classes was appropriate.

\section{Analysis of Section C}

Section C consisted of different questions that helped the researchers to explore the Pakistani ESL learners' perceptions about the overall effectiveness and likeability of online English teaching during the COVID-19 pandemic. Statistical values of Section C are shown in terms of percentage in the table mentioned below. 
Table 4: The Pakistani ESL Learners' Perceptions about the Overall Effectiveness and Likeability of Online English Teaching during the COVID-19 Pandemic

\begin{tabular}{|c|c|c|c|c|}
\hline Question No. \& Statement & $\begin{array}{l}\text { To A } \\
\text { Very } \\
\text { Littl } \\
\text { e } \\
\text { Exte } \\
\text { nt }\end{array}$ & $\begin{array}{l}\text { To } \\
\text { Some } \\
\text { Extent }\end{array}$ & $\begin{array}{l}\text { To A } \\
\text { Great } \\
\text { Extent }\end{array}$ & $\begin{array}{l}\text { To A } \\
\text { Very } \\
\text { Great } \\
\text { Extent }\end{array}$ \\
\hline $\begin{array}{l}\text { C.1. To what extent, you perceive online English } \\
\text { language classes during the COVID-19 pandemic } \\
\text { yielded positive outcomes. }\end{array}$ & $9 \%$ & $19 \%$ & $44 \%$ & $28 \%$ \\
\hline $\begin{array}{l}\text { C.2. To what extent, you perceive, online English } \\
\text { language teaching during the COVID-19 pandemic } \\
\text { helped you manage your pace to meet the } \\
\text { required deadline. }\end{array}$ & $10 \%$ & $27 \%$ & $34 \%$ & $29 \%$ \\
\hline $\begin{array}{l}\text { C.3. To what extent, you perceive online English } \\
\text { language teaching during the COVID-19 pandemic } \\
\text { got you motivated. }\end{array}$ & $11 \%$ & $29 \%$ & $36 \%$ & $24 \%$ \\
\hline $\begin{array}{l}\text { C.4. To what extent, you perceive online English } \\
\text { language lectures during the COVID-19 pandemic } \\
\text { were easy to be understood. }\end{array}$ & $7 \%$ & $24 \%$ & $40 \%$ & $29 \%$ \\
\hline $\begin{array}{l}\text { C.5. To what extent, you perceive online English } \\
\text { language teaching during the COVID-19 pandemic } \\
\text { developed your critical thinking skills. }\end{array}$ & $13 \%$ & $37 \%$ & $38 \%$ & $12 \%$ \\
\hline
\end{tabular}

The above mentioned table shows that $72 \%$ of the respondents ( $44 \%$ to a great extent and $28 \%$ to a very great extent) think that online English language classes during the COVID-19 pandemic yielded positive outcomes. $63 \%$ of the respondents $(34 \%$ to a great extent and 29 $\%$ to a very great extent) think online English language teaching during the pandemic helped them to manage their pace to meet the required deadline to a great extent, whereas $60 \%$ opine that online English language teaching during the pandemic motivated them to a great extent (36\% to a great extent and $24 \%$ to a very great extent). Moreover, $69 \%$ of the respondents ( $40 \%$ to a great extent and $29 \%$ to a very great extent) perceive that online English language lectures during the pandemic were easy to be understood. Half of the respondents $50 \%$ (38\% to a great extent and $12 \%$ to a very great extent) think that online English language teaching during the COVID-19 pandemic developed their critical thinking skills to a great extent.

\section{Discussion of Findings}

The findings of the study reveal that online English language teaching during the pandemic proved more useful for learners' listening, reading and vocabulary than learners' writing and speaking skills, and grammar. Thus, there is need that English language teachers employ such online tools and activities that may improve learners' writing and speaking skills, and grammar. Moreover, the learners found online English language teaching student centred. 
Learners were also satisfied with lectures' time duration, teachers' feedback and online examinations of English subject during the COVID-19 pandemic. But the learners were of the view that online English language teaching during the pandemic lacked regular formative assessment and interactive activities. Formative assessment is an important part of teaching. Its role is to assess learners' understanding of the lecture. Lack of formative assessment might be because of sudden shift of teachers from physical classes to online mode of education with little preparations and no training. The Government of Pakistan should start initiative and start mass class training of teachers on how to teach online in order to avoid such situation in future. Moreover, keeping in mind the findings of this study the teachers should also employ interactive activities in their online lectures. Learners were also satisfied with lectures' time duration, teachers' feedback and online examinations of English subject during the COVID-19 pandemic. On the whole, majority (72\%) of the respondents indicated that online English language teaching during the pandemic yielded positive results.

\section{Conclusion}

The current research work aimed at exploring the fact that how far online English language teaching remained effective during the pandemic in Pakistan. Data Findings of the study reveal that online English language teaching during the COVID-19 pandemic proved useful for the listening skills (42\% very useful, $30 \%$ useful), reading skills (30 \% very useful, $26 \%$ useful) and vocabulary (14\% very useful, $45 \%$ useful) of the Pakistani ESL learners. Moreover, $64 \%$ agreed (10 \% strongly agree, $54 \%$ agree) with the view that online English language teaching during the pandemic remained student centred. Learners were also satisfied with lectures' time duration, teachers' feedback and online examinations of English subject during the COVID-19 pandemic. On the whole, $72 \%$ (44 \% to a great extent and $28 \%$ to a very great extent) of the respondents indicated that online English language teaching during the pandemic yielded positive results to a great extent.

\section{References}

${ }^{1}$ Huang, Chaolin, Yeming Wang, Xingwang Li, Lili Ren, Jianping Zhao, Yi Hu, Li Zhang et al. "Clinical features of patients infected with 2019 novel coronavirus in Wuhan, China." The lancet 395, no. 10223 (2020): 497-506. https://doi.org/10.1016/S0140-6736(20)30183-5. [Google Scholar]

2 World Health Organization, "Coronavirus disease (COVID-19) pandemic," https://www.who.int/emergencies/diseases/novel-coronavirus-2019 (accessed July 17, 2021.)

3 Li, Chen and Farah Lalani. "The COVID-19 pandemic has changed education forever," World economic forum (Vol. 29). April 29, 2020. accessed July 13, 2021. https://www.weforum.org/agenda/2020/04/coronavirus-education-global-covid19-online-digitallearning/.

4 Yu, Wenchi. “Online English language learning in the time of COVID-19.” Asia Society. May 08, 2020. accessed July 13, 2021. https://asiasociety.org/asia21-young-leaders/online-english-languagelearning-time-covid-19

5 The United Nations Educational, Scientific and Cultural Organization. "COVID-19: 10

Recommendations to plan distance learning solutions," Accessed July 122021.

https://en.unesco.org/news/covid-19-10-recommendations-plan-distance-learning-solutions 
${ }^{6}$ Thaheem, Sahib Khatoon, Mohamad Jafre Zainol Abidin, Quratulain Mirza, and Habib Ullah Pathan. "Online teaching benefits and challenges during pandemic COVID-19: a comparative study of Pakistan and Indonesia." Asian Education and Development Studies (2021). https://doi.org/10.1108/AEDS-08-2020-0189

${ }^{7}$ Mathivanan, Sandeep Kumar, Prabhu Jayagopal, Shakeel Ahmed, S. S. Manivannan, P. J. Kumar, Kiruba Thangam Raja, S. Sree Dharinya, and R. Giri Prasad. "Adoption of e-learning during lockdown in India." International Journal of System Assurance Engineering and Management (2021): 1-10. https://doi.org/10.1007/s13198-021-01072-4

${ }^{8}$ Ahmady, Soleiman, Sara Shahbazi, and Mohammad Heidari. "Transition to Virtual Learning During the Coronavirus Disease-2019 Crisis in Iran: Opportunity Or Challenge?." Disaster medicine and public health preparedness 14, no. 3 (2020): e11-e12.

${ }^{9}$ Younesi, Mehrdad. "Virtual Teaching of English Language During COVID-19 Pandemic in Iran: Views and Attitudes." NOVYI MIR (2021): 15-21.

10 Oraif, Iman, and Tariq Elyas. "The Impact of COVID-19 on Learning: Investigating EFL Learners' Engagement in Online Courses in Saudi Arabia." Education Sciences 11, no. 3 (2021): 99. https://www.mdpi.com/2227-7102/11/3/99/pdf

${ }^{11}$ Asgari, Shadnaz, Jelena Trajkovic, Mehran Rahmani, Wenlu Zhang, Roger C. Lo, and Antonella Sciortino. "An observational study of engineering online education during the COVID-19 pandemic." Plos one 16, no. 4 (2021): e0250041. https://doi.org/10.1371/journal.pone.0250041

12 König, Johannes, Daniela J. Jäger-Biela, and Nina Glutsch. "Adapting to online teaching during COVID-19 school closure: teacher education and teacher competence effects among early career teachers in Germany." European Journal of Teacher Education 43, no. 4 (2020): 608-622.

${ }^{13}$ Farooq, Fareeha, Farooq Azam Rathore, and Sahibzada Nasir Mansoor. "Challenges of online medical education in Pakistan during COVID-19 pandemic." J Coll Physicians Surg Pak 30, no. 6 (2020): 67-69.

${ }^{14}$ Khan, Rehan Ahmed, and Masood Jawaid. "Technology enhanced assessment (TEA) in COVID 19 pandemic." Pakistan journal of medical sciences 36, no. COVID19-S4 (2020): S108-S110.

15 Mumtaz, Nazia, Ghulam Saqulain, and Nadir Mumtaz. "Online academics in Pakistan: COVID-19 and beyond." Pakistan Journal of Medical Sciences 37, no. 1 (2021): 283-287. https://doi.org/10.12669/pjms.37.1.2894

${ }^{16}$ Paivio, Allan, and J. M. Clark. "Dual coding theory and education." In Draft chapter presented at the conference on Pathways to Literacy Achievement for High Poverty Children at The University of Michigan School of Education. Citeseer, 2006.

17 Paivio, Allan, and J. M. Clark. "Dual coding theory and education." In Draft chapter presented at the conference on Pathways to Literacy Achievement for High Poverty Children at The University of Michigan School of Education. Citeseer, 2006.

18 Mayer, Richard E. "Cognitive theory of multimedia learning." The Cambridge handbook of multimedia learning 41 (2005): 31-48.

${ }^{19}$ Johnson, Cheryl I., and Richard E. Mayer. "A testing effect with multimedia learning." Journal of Educational Psychology 101, no. 3 (2009): 621.

${ }^{20}$ Shahzad, Syed Khuram, Javaid Hussain, Nadia Sadaf, Samina Sarwat, Usman Ghani, and Robina Saleem. "Impact of Virtual Teaching on ESL Learners' Attitudes under COVID-19 Circumstances at Post Graduate Level in Pakistan." English Language Teaching 13, no. 9 (2020): 1-9.

${ }^{21} \mathrm{Yu}$, Wenchi. "Online English language learning in the time of COVID-19." Asia Society. May 08, 2020. https://asiasociety.org/asia21-young-leaders/online-english-language-learning-time-covid-19 (accessed July 13, 2021).

${ }^{22} \mathrm{Li}$, Chen and Farah Lalani. "The COVID-19 pandemic has changed education forever," World economic forum (Vol. 29). April 29, 2020. https://www.weforum.org/agenda/2020/04/coronaviruseducation-global-covid19-online-digital-learning/ (accessed July 13, 2021). 
${ }^{23}$ Singh, Ranjana and Ritika Tiwari. " Online learning as future transition of education in Indian prospect." Journal of Engineering \& Technology 7, no. 1 (2021): 1-32.

24 https://www.vipkid.com/

${ }^{25} \mathrm{Yu}$, Wenchi. "Online English language learning in the time of COVID-19." Asia Society. May 08, 2020. https://asiasociety.org/asia21-young-leaders/online-english-language-learning-time-covid-19 (accessed July 13, 2021).

${ }^{26}$ Harrison, Graeme. "English teaching and learning during the Covid crisis: online classes and upskilling teachers." May 04, 2020. https://www.cambridgeenglish.org/blog/english-teachingand-learning-during-the-covid-crisis/ (accessed July 23, 2021).

27 Mumtaz, Nazia, Ghulam Saqulain, and Nadir Mumtaz. "Online academics in Pakistan: COVID-19 and beyond." Pakistan Journal of Medical Sciences 37, no. 1 (2021): 283-287

${ }^{28}$ Rehman, Aziz Ur. "Challenges to Online Education in Pakistan During COVID-19 \& the Way Forward." AIJR Preprints 241, no. 1 (2020).

${ }^{29}$ Trizano-Hermosilla, Italo, and Jesús M. Alvarado. "Best alternatives to Cronbach's alpha reliability in realistic conditions: congeneric and asymmetrical measurements." Frontiers in psychology 7 (2016): 769. https://internaljournal.frontiersin.org/articles/10.3389/fpsyg.2016.00769/full

30 George, D., and P. Mallery. "SPSS for Windows step by step: A simple guide and reference. 11.0 update. wps. ablongman. com/wps/media/objects/385." George 4answers pdf 549 (2003). 